\title{
Medicinal Signaling Cells Metabolite Oral Based as a Potential Biocompatible Biomaterial Accelerating Oral Ulcer Healing (In Vitro Study)
} \author{
Fedik Abdul Rantam ${ }^{1,5}$ \\ ${ }^{1}$ Stem Cell Research and Development Center, Universitas Airlangga \\ Surabaya, Indonesia \\ 2Orthodontics Department, Faculty of Dental Medicine, Universitas \\ Airlangga, Surabaya, Indonesia \\ ${ }^{3}$ Doctoral Student of Medical Science, Faculty of Medicine, \\ Universitas Airlangga, Surabaya, Indonesia \\ ${ }^{4}$ Oral Medicine Department, Faculty of Dental Medicine, Universitas \\ Airlangga, Surabaya, Indonesia \\ 5 Virology and Immunology Laboratory, Department of \\ Microbiology, Faculty of Veterinary Medicine, Universitas \\ Airlangga, Surabaya, Indonesia
}

Alexander Patera Nugraha ${ }^{1,2,3}$ Purwati ${ }^{1}$ Helen Susilowati ${ }^{1}$ Eryk Hendrianto ${ }^{1}$ Deya Karsari ${ }^{1}$ Nora Ertanti ${ }^{1}$ Aristika Dinaryanti ${ }^{1}$ Igo Syaiful Ihsan ${ }^{1}$ Ida Bagus Narmada ${ }^{2}$ Diah Savitri Ernawati ${ }^{4}$

\begin{abstract}
Address for correspondence Fedik Abdul Rantam, DVM, Virology and Immunology Laboratory, Department of Microbiology, Faculty of Veterinary Medicine, Universitas Airlangga, Surabaya, Airlangga University, Jl. Mulyosari Campus C Airlangga University, Surabaya 60132, Indonesia (e-mail: fedik-a-r@fkh.unair.ac.id).
\end{abstract}

Eur J Dent 2019;13:432-436

Evr)

\begin{abstract}
Keywords

- medicinal signaling cells

- wound healing

- biomaterial

- metabolite

- biocompatibility

Objective Medicinal signaling cells metabolite (MSCM) is often considered medical waste even though it contains abundant growth factors, and advantageous micro- and macromolecules that can accelerate healing in oral ulcer.

The purpose of this experimental laboratory study was to analyze the biocompatibility and potential of MSCM, (oral based) to accelerate healing in oral ulcer (in vitro).

Materials and Methods MSCM (oral based) was obtained by mixing $10 \mathrm{~mL}$ of MSCM and $2 \%$ of carboxymethyl cellulose sodium. 3- (4,5-dimethylthiazol-2-yl)-2,5-diphenyltetrazolium bromide (or MTT assay) was obtained using human gingival somatic cell culture to examine cell viability treated with MSCM (oral based). Fourier transform infrared spectroscopy was performed to know the functional structure and composition of MSCM (oral based). To know the elemental composition of MSCM (oral based), energy-dispersive X-ray analysis was performed. Scratch test was performed to know the ability of MSCM (oral based) to increase human somatic cell proliferation.

Results MSCM (oral based) has good cell viability. MSCM (oral based) administration accelerated the proliferation of human somatic cell culture after 12-hours in vitro. MSCM (oral based) has carboxylic acids and derivatives chemical bond. MSCM (oral based) mostly contained carbon and potassium but did not contain heavy metal substances.

Conclusions MSCM (oral based) has a biocompatible and potential ability to accelerate healing in oral ulcer in vitro. It would be useful in daily clinical practice in treating traumatic oral ulcer.
\end{abstract}

\section{Introduction}

Sharp orthodontic appliances can lead to oral tissue injury. Traumatic oral ulcers are frequently related to sharp orthodontic brackets or wires that irritate the oral mucosa. The destruction of the oral epithelium is marked by irregular laceration or ulcer surrounding the erythema area and nerve ending exposure. Traumatic oral ulcers caused by sharp 
orthodontic appliances can cause unpleasant and painful sensation. ${ }^{1}$ According to the Khan et al study, oral mucosa lesions-such as $40 \%$ patients with erosion and $45 \%$ patients with ulceration-frequently occur during fixed orthodontic treatment. ${ }^{2}$ Traumatic oral ulcer incidences range from 60 to $81 \%$. An estimated $47 \%$ traumatic oral ulcer incidences occurred in adults with the most unpleasant sensation during orthodontic treatment; $29 \%$ of adolescents report ulcers as the second-most discomfort aspect of orthodontic treatment..$^{1,3}$

Painful sensation is part of the inflammatory response during healing that occurs $\sim 24$ hours. ${ }^{4}$ Oral ulcers normally heal in $\sim 10$ to 14 days, but sometimes if there is infection, it can prolong and delay the healing process. ${ }^{1,4}$ The infection stimulates pro-inflammatory cytokines such as tumor necrosis factor- $\alpha$ and interleukin-1 $\beta$. Those pro-inflammatory cytokines stimulate the synthesis of matrix metalloprotease-9, which can lead to Extracellular Matrix degradation. ${ }^{5}$ There are so many normal commensal flora in the oral cavity. Although saliva has antimicrobial properties like human beta defensin-2 as antimicrobial peptide (AMPs), the microenvironment in the oral mucosa is very challenging for oral ulcer healing due to pathogen microorganisms in the oral cavity that can induce an inflammatory response. ${ }^{6,7}$

So many products and drugs, with different formulations and various active compounds, were used to treat oral ulcers. ${ }^{8,9}$ The Karavana Hizarcioğlu et al study mentioned that chlorhexidine or benzydamine hydrochloride is no better than a placebo mouthwash. Ulcers treated with benzydamine hydrochloride gel reduced $33 \%$ more than ulcers in control groups, but they were still not healed until the 12th day. ${ }^{9}$ Ernawati and Puspa and Puspasari et al studies used herbal compounds such as propolis gel to treat oral ulcers, while an Apriasari et al study used mauli banana stem extract gel as an anti-inflammatory agent to treat oral ulcers, but the healing process accelerated after a few days., ${ }^{4,5,10}$

Medicinal signaling cells or mesenchymal stem cells (MSC) possessed the ability to accelerate wound healing. ${ }^{11}$ During MSC culture in medium, MSC secreted a lot of beneficial cytokines, AMPs, molecules, and growth factors in the culture medium that were very useful. ${ }^{12,13}$ After MSC was harvested, the MSC culture medium was discarded and become medical waste. The MSC culture medium can be purified and can be used again as biomaterial to accelerate oral ulcer healing. ${ }^{14}$

We would like to make the promising biomaterial, which has great biocompatibility and potential ability to accelerate oral ulcer healing by MSCM (oral based). The aim of this study was to analyze the analyze the biocompatibility and potential of MSCM (oral based) accelerating oral ulcer healing (in vitro). This is important and useful because traumatic oral ulcer is a major problem during fixed orthodontic treatment that has yet to be resolved.

\section{Materials and Methods}

This study was conducted in an experimental laboratory with a descriptive analysis observational study and a randomized control group design. The study received ethical clearance with number 289/HRECC.FODM/XII/2017 from Faculty of Dental Medicine, Universitas Airlangga, Surabaya.

\section{Formulation of Medicinal Signaling Cells Metabolite (Oral Based)}

The MSCM (oral based) gel was made in accordance with the procedures of the Stem Cell Research and Development Center by mixing $10 \mathrm{ml}$ of MSC metabolite with $2 \%$ of carboxymethyl cellulose sodium ( - Fig. 1) ${ }^{14}$

\section{3-(4,5-Dimethylthiazol-2-yl)-2,5-Diphenyltetrazolium Bromide or MTT assay}

3-(4,5-dimethylthiazol-2-yl)-2,5-diphenyltetrazolium bromide (or MTT assay) was performed using human gingival somatic cell (GSC) culture in accordance with the procedure prescribed in the Prahasanti et al study..$^{15}$ GSCs were isolated and cultured according to the procedure prescribed in the Nugraha et al study. ${ }^{16-18}$

Furthermore, the samples were divided into two groups: cells treated with MSCM (oral based) were the treatment group and cells without MSCM (oral based) were the control group. The number of living cells was then observed by calculating CD50 with the MTT assay. MTT absorbency was indicated with a crystal formazan blue purple colored was examined by means of enzyme-linked immunosorbent assay reader using 550 to $620 \mathrm{~nm}$ wavelength. The MTT assay was done at the Stem Cell Research and Development Center, Surabaya, Indonesia.

\section{Scratch Test}

A scratch test was done at the Stem Cell Research and Development Center, Surabaya, Indonesia. The scratch test was performed to know the ability of MSCM (oral based) to stimulate human somatic cell proliferation and migration, assessed with cell migration into the cell-free field, in accordance with the Rantam study.$^{14}$ Human somatic cells were cultured in an $\mathrm{m} 24$ culture plate with estimated $5.10^{4}$ cells in each well, then incubated at $37^{\circ} \mathrm{C}$ in an incubator (Sigma Aldrich, US). Each well was scratched with blue tip (Sigma Aldrich, US) with plus (+) shape. The samples were divided into four groups $(n=1)$ : A. Control group; B. 0 hour treated with MSCM (oral based); C. 3 hours treated with MSCM (oral based); D. 12 hours treated with MSCM (oral based). The culture plate of each group was examined by means of a light microscope with 100x magnification (Olympus, Japan). Images were taken with a camera (Olympus, Japan).

\section{Fourier-Transform Infrared Spectroscopy and Energy Dispersive X-Ray Analysis}

The MSCM (oral based) product was examined by means of Fourier transform infrared spectroscopy (FTIR) to know its functional structure and composition, and to know the elemental composition of MSCM (oral based), an energy dispersive X-ray (EDX) analysis was performed. The EDX and FTIR analyses were done accordance with the procedure of the Prahasanti et al and Nugraha et al studies. ${ }^{15,16}$ Both analyses was done at the Laboratory of Technical Industrial Faculty, Institute of Technology Sepuluh Nopember, Surabaya, Indonesia. 


\section{Results}

The optical density of MSCM (oral based) can be seen in -Fig. 2. The MTT assay examination result showed that MSCM (oral based) has a high viability to human somatic cell culture (-Fig. 3). The scratch test result showed that MSCM (oral based) administration accelerated the proliferation of somatic cell culture after 12 hours in vitro (-Fig. 4 ). The FTIR examination showed a functional structure and composition of MSCM (oral based) that can be seen in - Fig. 5. It has Carboxylic Acids \& Derivatives bond with peak 3270.11 . The EDX examination showed that MSCM (oral based) mostly contained Carbon Potassium and it did not contain heavy metal substances (-Fig. 6). The composition of MSCM (oral based) can be seen in -Table 1 .

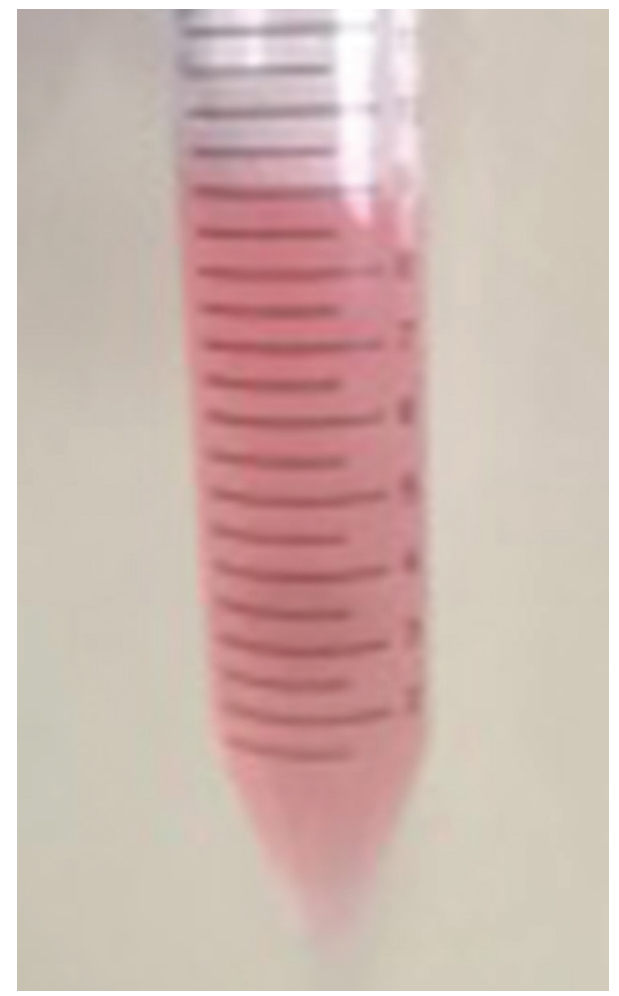

Fig. 1 Medicinal signaling cells metabolite (oral-based) product.

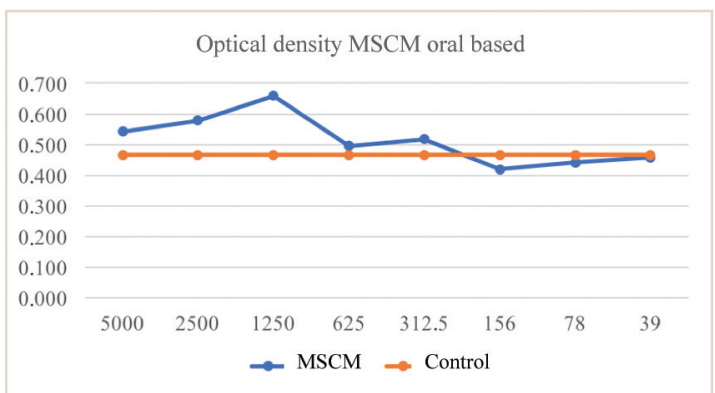

Fig. 2 Optical density of medicinal signaling cells metabolite (MSCM) (oral based).

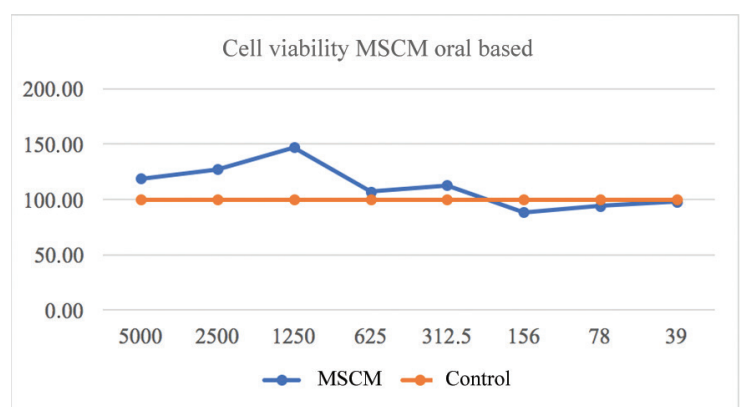

Fig. 3 Cell viability of medicinal signaling cells metabolite (MSCM) (oral based).
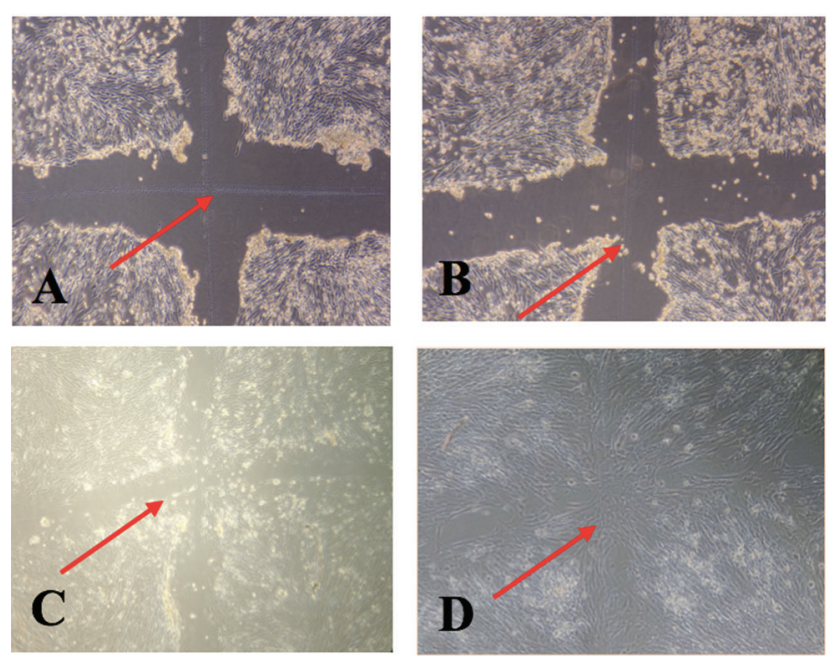

Fig. 4 Scratch test to examine somatic cell proliferation ability (in vitro) examined using electron microscope with 100x magnification (Olympus, Japan). (A) Control group, (B) 0 hour treated with medicinal signaling cells metabolite (MSCM) (oral based); (C) 3 hours treated with MSCM oral-based product; (D) 12 hours treated with MSCM (oral based).

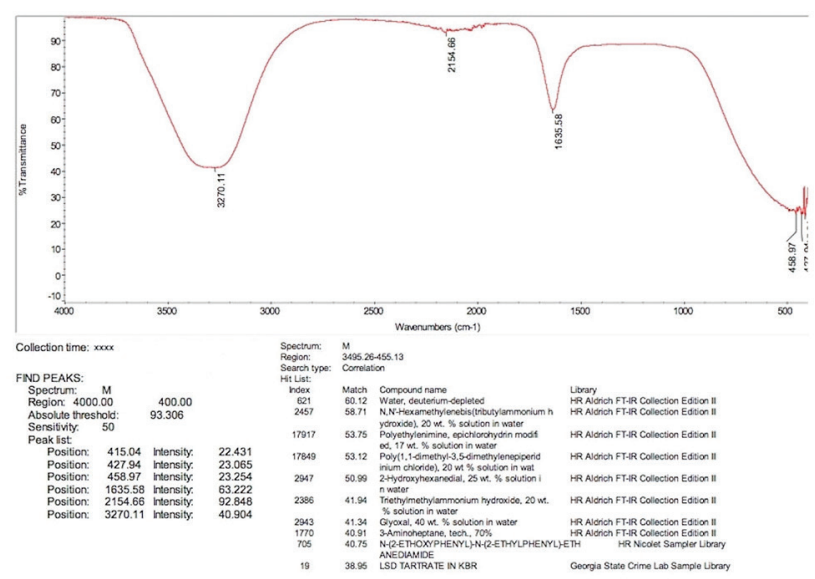

Fig. 5 Fourier-transform infrared spectroscopy result of medicinal signaling cells metabolite oral-based functional structure and composition.

\section{Discussion}

The successfulness oral ulcer treatment depends on several factors such as the elimination of etiology factor, minimalize 


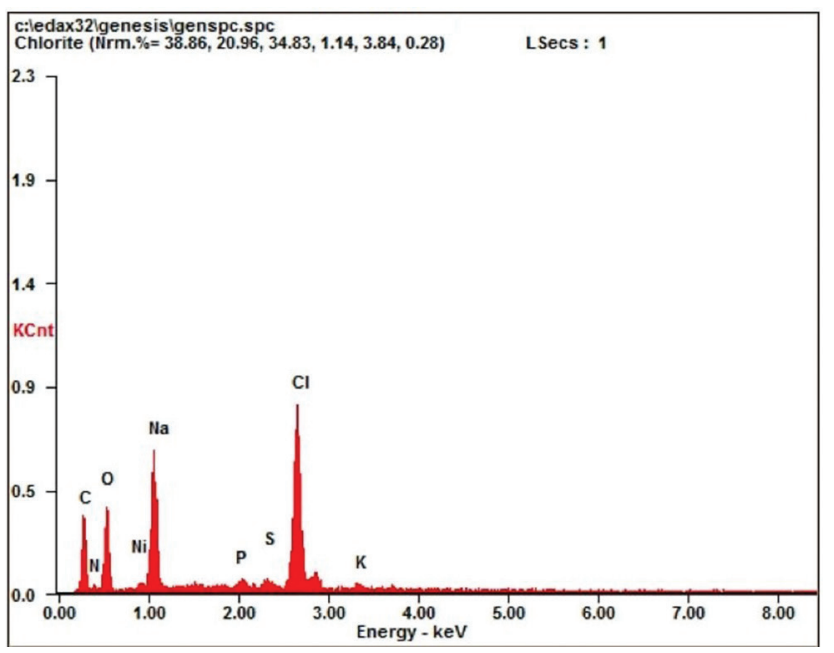

Fig. 6 Energy-dispersive X-ray result of medicinal signaling cells metabolite oral-based product.

Table 1 Element composition analysis using EDX of MSCM oral based

\begin{tabular}{|l|l|l|}
\hline Element & Wt\% & At\% \\
\hline C K & 28.06 & 40.81 \\
\hline N K & 04.40 & 05.49 \\
\hline O K & 26.59 & 29.04 \\
\hline Ni L & 01.19 & 00.35 \\
\hline Na K & 17.44 & 13.25 \\
\hline P K & 00.86 & 00.48 \\
\hline S K & 00.87 & 00.47 \\
\hline Cl K & 19.67 & 09.69 \\
\hline K K & 00.92 & 00.41 \\
\hline
\end{tabular}

Abbreviations: EDX, energy-dispersive X-ray; MSCM, medicinal signaling cells metabolite.

the pathogen or commensal microorganism in the oral niche that can delay healing. ${ }^{45,10}$ A biocompatible biomaterial that supports cell, and the potential growth factor in biomaterial to support endogenous cell metabolic activities is necessary needed. ${ }^{17-19}$ MSCM (oral based) has good cell viability in GSCs examined by the MTT assay. GSCs can be easily isolated with noninvasive methods from free-margin gingiva in the oral cavity. ${ }^{20} \mathrm{GSC}$ s are suitable cells for cytotoxicity test purpose. ${ }^{21}$ It can be said that MSCM (oral base) is a biocompatible material for application in the oral cavity. Surprisingly, MSCM (oral based) did not decrease the cell number during the MTT assay but increased it. MSCs during culture secreted abundant advantageous growth factors through paracrine and autocrine pathways such as vascular endothelial growth factor, fibroblast growth factor, and insulin growth factor, which support cell metabolism, proliferation, and differentiation..$^{22-24}$ The scratch test support the fact that growth factor contained in MSCM (oral based) can increase cell proliferation after 12 hours. MSCM (oral based) stimulates migration factors such as CXC motif chemokine ligand 12 and stromal-derived factor-1 that made communication of the cells happen. In addition, cells secreted various growth factors to support cell proliferation..$^{24-27}$ The Somoza et al study also mentioned that MSCs secreted antimicrobial peptides such as Cathelicidin against microorganism and Immunomodulation molecules like Indoleamine 2,3-dioxygenase. ${ }^{12}$ Those beneficial molecules are very useful for tissue regeneration caused by injury. At the injury sites, MSCs focus their local immunomodulatory and trophic activities. ${ }^{24-27}$

The FITR results of this study revealed the function and structure of MSCM (oral based). FTIR spectroscopy will result in a powerful tool in the study and diagnosis of biological systems. FTIR spectroscopy is a rapid, noninvasive, accurate, and efficient technique to examine biomaterial. ${ }^{15}$ The structural organization of MSCM (oral based) is an important matrix for retaining the cells at a specific site and initiating appropriate cell-to-cell interactions and migration. ${ }^{22}$

EDX is very useful in the biomedical fields because of its high sensitivity to examine the different elements in tissues. EDX is generally used to improve the biomaterial or chemotherapeutic agents. EDX is also an important tool to detect nanoparticles. ${ }^{28}$ In this study, EDX was performed to examine the composition of MSCM (oral based). MSCM (oral based) was a safe biomaterial because it did not contain heavy metal substances such as lead $(\mathrm{Pb})$, nickel $(\mathrm{Ni})$, zinc $(\mathrm{Zn})$, cadmium $(\mathrm{Cd})$, chromium $(\mathrm{Cr})$, copper $(\mathrm{Cu})$, or mercury $(\mathrm{Hg})$. EDX can be used to detect heavy metal substances due to pollution in the environmental. Heavy metals are nonbiodegradable substances. These are the biggest problem for the environment, and they can accumulate and negatively affect the human body. ${ }^{29}$

\section{Conclusion}

MSCM (oral based) has a biocompatible and potential ability to accelerate healing in oral ulcer in vitro. It would be useful in daily clinical practice in treating traumatic oral ulcer.

\section{Conflict of Interest}

None declared.

\section{Acknowledgments}

The author would like to thank Stem Cell Research and Development Center, Universitas Airlangga; Faculty of Dental Medicine, Universitas Airlangga, Faculty of Veterinary Medicine, Universitas Airlangga, Surabaya, Indonesia and also Technical Industrial Faculty of Institute of Technology Sepuluh November (ITS) Surabaya, Indonesia for supporting our study.

\section{References}

1 Rennick LA, Campbell PM, Naidu A, Taylor RW, Buschang PH. Effectiveness of a novel topical powder on the treatment of traumatic oral ulcers in orthodontic patients: a randomized controlled trial. Angle Orthod 2016;86(3):351-357 
2 Khan RMS, Hassan KR, Rizwan M. Prevalence and type of oral mucosal lesion in patient with fixed orthodontic appliances. Ashraf J Med Forum 2016;27(4):12-16

3 Kvam E, Bondevik O, Gjerdet NR. Traumatic ulcers and pain in adults during orthodontic treatment. Community Dent Oral Epidemiol 1989;17(3):154-157

4 Puspasari A, Harijanti K, Soebadi B, Hendarti HT, Radithia D, Ernawati DS. Effects of topical application of propolis extract on fibroblast growth factor-2 and fibroblast expression in the traumatic ulcers of diabetic Rattus norvegicus. J Oral Maxillofac Pathol 2018;22(1):54-58

5 Ernawati DS, Puspa A. Expression of vascular endothelial growth factor and matrix metalloproteinase-9 in. Apis mellifera. Lawang propolis extract gel-treated traumatic ulcers in diabetic rats. Vet World 2018;11(3):304-309

6 Kusumaningsih T, Subijanto MS, Indrawati R, Devijanti RR. The level of beta defensin-2 in saliva and its expression in parotid gland epithelial cells after probiotic (Lactobacillus reuteri) induction to inhibit Streptococcus mutans in caries. Eur J Dent 2016;10(4):556-560

7 Jiang Y, Magli L, Russo M. Bacterium-dependent induction of cytokines in mononuclear cells and their pathologic consequences in vivo. Infect Immun 1999;67(5):2125-2130

8 Descroix V, Coudert AE, Vigé A, et al. Efficacy of topical 1\% lidocaine in the symptomatic treatment of pain associated with oral mucosal trauma or minor oral aphthous ulcer: a randomized, double-blind, placebo-controlled, parallel-group, single-dose study. J Orofac Pain 2011;25(4):327-332

9 Karavana Hizarcioğlu SY, Sezer B, Güneri P, et al. Efficacy of topical benzydamine hydrochloride gel on oral mucosal ulcers: an in vivo animal study. Int J Oral Maxillofac Surg 2011;40(9):973-978

10 Apriasari ML, Rahayu RP, Ernawati DS. Mauli banana stem extract application increased expression of NFKB in traumatic ulcer healing. Majalah Kedokteran Gigi 2018;51(2):62-70

11 Caplan AI. Mesenchymal stem cells: time to change the name! Stem Cells Transl Med 2017;6(6):1445-1451

12 Somoza RA, Correa D, Caplan AI. The role of mesenchymal stem cells as medicinal signaling cells. Nature protocol and recipe for researchers. Nat Protoc 2017;11(1):1

13 Tanabe $S$. Role of mesenchymal stem cells in cell life and their signaling. World J Stem Cells 2014;6(1):24-32

14 Rantam FA, Ferdiansyah, Purwati. Mesenchymal Stem cell, Hematopoietic Stem Cells, and Application Model. 2nd ed. Surabaya: Airlangga University Press; 2015

15 Prahasanti C, Wulandari DT, Ulfa N. Viability test of fish scale collagen (Oshpronemus gouramy) on baby hamster kidney fibroblasts-21 fibroblast cell culture. Vet World 2018;11(4):506-510
16 Nugraha AP, Rantam FA, Ernawati DS, et al. Gingival mesenchymal stem cells from Wistar rat's gingiva (Rattus norvegicus) isolation and characterization (in vitro study) J Int Dent Med Res 2018;11(2):694-699

17 Nugraha AP, Narmada IB, Ernawati DS, et al. Somatic cells acceleration by platelet rich fibrin. Indian Vet J 2019;96(04):30-34

18 Nugraha AP, Narmada IB, Ernawati DS, et al. In vitro bone sialoprotein-I expression in combined gingival stromal cells and platelet rich fibrin during osteogenic differentiation. Trop J Pharm Res 2018;17(12):2341-2345

19 Nugraha AP, Narmada IB, Ernawati DS, et al. Bone alkaline phosphatase and osteocalcin expression of rat's Gingival mesenchymal stem cells cultured in platelet-rich fibrin for bone remodeling (in vitro). study) Eur J Dent 2018;12(4):566-573

20 Nugraha AP, Narmada IB, Ernawati DS, et al. Osteogenic potential of gingival stromal progenitor cells cultured in platelet rich fibrin is predicted by core-binding factor subunit- $\alpha 1 /$ Sox 9 expression ratio (in vitro). F1000 Res 2018;7:1134

21 Nugraha AP, Narmada IB, Ernawati DS, et al. The Aggrecan expression post platelet rich fibrin administration in gingival medicinal signaling cells in Wistar rats (Rattus norvegicus) during the early osteogenic differentiation (in vitro) Kafkas Univ Vet Fak Derg 2019;25(3):421-425

22 Lai RC, Yeo RWY, Tan SS, Zhang B, Yin Y, Sze NSK, Mesenchymal Stem Cell Exosomes: The Future MSC-Based Therapy? Mesenchymal Stem Cell Therapy: Springer 2013;39-61

23 Carvalho MM, Teixeira FG, Reis RL, Sousa N, Salgado AJ. Mesenchymal stem cells in the umbilical cord: phenotypic characterization, secretome and applications in central nervous system regenerative medicine. Curr Stem Cell Res Ther 2011;6(3):221-228

24 Bernardo ME, Fibbe WE. Mesenchymal stromal cells: sensors and switchers of inflammation. Cell Stem Cell 2013;13(4):392-402

25 Caplan AI, Correa D. The MSC: an injury drugstore. Cell Stem Cell 2011;9(1):11-15

26 Caplan AI, Sorrell JM. The MSC curtain that stops the immune system. Immunol Lett 2015;168(2):136-139

27 Vazquez-Zapien GJ, Mata-Miranda MM, Sanchez-Monroy V, Delgado-Macuil RJ, Perez-Ishiwara DG, Rojas-Lopez M. FTIR spectroscopic and molecular analysis during differentiation of pluripotent stem cells to pancreatic cells. Stem Cells Int 2016;2016:6709714

28 Scimeca M, Bischetti S, Lamsira HK, Bonfiglio R, Bonanno E. Energy dispersive X-ray (EDX) microanalysis: a powerful tool in biomedical research and diagnosis. Eur $\mathrm{J}$ Histochem 2018;62(1):2841

29 Singh R, Gautam N, Mishra A, Gupta R. Heavy metals and living systems: an overview. Indian J Pharmacol 2011;43(3):246-253 